\title{
Effect of Hingulamrutadi malahara in the management of dushta vrana
}

\author{
Research article
}

\section{Prem Chandra ${ }^{1}$, Gopikrishna BJ ${ }^{2}$, Avnish Pathak ${ }^{3}$, Hemantha Kumar $\mathrm{P}^{4}$}

1. P.G.Scholar, 2.Guide, 3. Associate Professor, 4. HOD

Dept. of ShalyaTantra, SDM College of Ayurveda \& Hospital, Hassan, Karnataka, India

\begin{abstract}
Dustavrana is a common and frequently encountered problem faced in surgical practice. The presence of Dushtavrana(1) worsens the condition of the patient with different complications and may become fatal. Local factors on wound like slough, infection and foreign body, affect the normal process of healing. A healthy wound in a normal body heals earlier with a minimum scar as compared to a contaminated wound. Therefore in this study all the efforts are made to make a Dustvrana into a shuddhavrana. (2) Once the vrana becomes shuddha, ropana of the vrana will start. The objective of the study was to evaluate the Shodhana and Ropana effect of HingulamrutadiMalahara in Dushtavrana compared with standard Jatyadi Ghrita.

Clinically diagnosed 40 Patients of Dushtavrana were randomly divided into two groups, each consisting of 20 Patients. H group were treated with the HingulamrutadiMalahara treated group. J Group as a control group was treated by JatyadiGhrita.

On the basis of assessment criteria and overall result of treatment, the patients of Hingulamrutadi Malahara group showed better results when compared to Jatyadi Ghrita group.

Hingulamrutadi Malahara has provided good relief in most of the signs and symptoms of the patients of Dushtavrana, in comparison to Jatyadi Ghrita. Its overall effects were good in comparison to Jatyadi Ghrita.
\end{abstract}

Key words: Dusta Vrana, Hingulmrutadi Malahara, Jatyadi Ghrita

\section{Introduction:}

Science is not merely a collection of facts \& relationship but is more than composite of these facts, accumulated \& systematically correlated over the ages.Classics of Ayurveda has emphasized at various places to take care of wounds

*Corresponding Author:

\section{Prem Chandra,}

Final year P.G, Scholar, Dept. of ShalyaTantra,

SDM College of Ayurveda \& Hospital,

Hassan, Karnataka, India

Ph.no: +91-9980691111

Email: drpremms@gmail.com which occur either as a result of vitiated Doshas or are traumatic in origin.

Shalyatantra is one of the important branch of Ayurveda in which surgical and parasurgical techniques have been described for management of various diseases. Vrana is one of them which is being managed by human being from starting of civilization.

Under the circumstances the first thing with which the men came across was the injury fromdifferent sources which caused him the Vrana (wound). Vrana is seen as debilitatingand scaring disorder usually seen affecting the human being at any age. 
While explaining the scope of Shalyatantra, Sushruta has mentioned Vrana Vinishcayart (3) as a major part of Shalyatantra.

Even though healing of Vrana is a natural process of the body, the Vrana should be protected from Dosha Dushti (4) and from various micro-organisms, which may affect the Vrana and delay the normal healing process. So, for the early and uncomplicated healing of Vrana, treatment is necessary.

\section{Material and Methods:}

Clinically diagnosed 40 Patients of Dushtavrana were randomly divided into two groups, each consisting of 20 Patients.

\section{Group 1: Hingulamrutadi Malahara(H Group):}

The patients of this group were applied by Hingulamrutadi Malahara(5) once a day and bandaged.

\section{Group 2: Jatyadi Ghrita (J Group):}

The patients of this group were applied by Jatyadi Ghrita, once in a day and properly bandaged.

\section{Drug:}

Method of preparation of Hingulamrutadi Malahara

Ingredients:

$\begin{array}{lll}\text { Hingula } & - & 1 \text { part } \\ \text { Siktha } & - & 2 \text { parts } \\ \text { Tankana } & - & 1 / 6 \text { parts } \\ \text { Rasa Karpura } & - & 1 / 6 \text { parts } \\ \text { Spatika } & - & 1 / 6 \text { parts }\end{array}$

Ingredients for Taila Paka:

\section{Pancha Valkala}

$\begin{array}{lll}\text { Kashaya } & - & 8 \text { parts } \\ \text { Nirgundi Svarasa } & - & 8 \text { parts } \\ \text { Tila Taila } & - & 4 \text { parts } \\ \text { Kalka of Arka } & - & 1 / 2 \text { part } \\ \text { Kalka of Haridra } & - & 1 / 2 \text { part }\end{array}$

Figure No 1

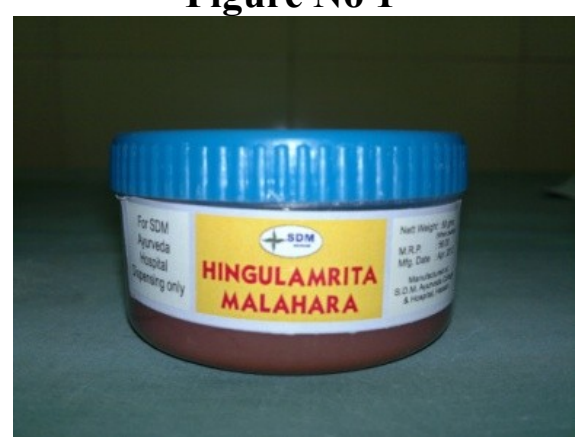

Figure No.2

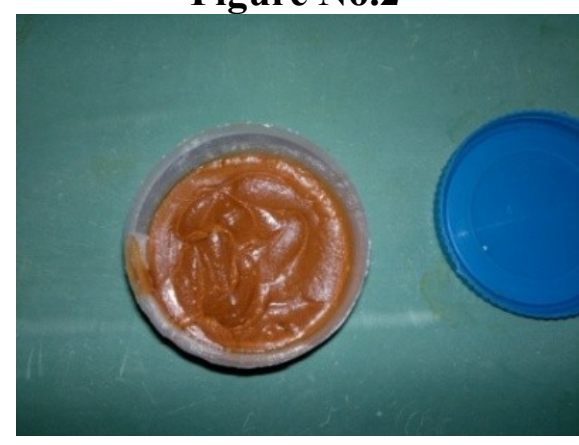

With the Pancha Valkala Kashaya, Nirgundi Svarasa, Tila Taila, Kalka of Haridra and Arka the Taila Paka is done.To this 24 gm of Siktha is added and stirred well till it becomes homogenous mixture .To this fine powders of Hingula, Tankana, Rasa Karpura, Spatika, are added and mixed well and kept in air tight container.

Table No - 1 Showing the Grouping of the Patients

\begin{tabular}{|l|l|l|}
\hline Group & Treatment & Duration \\
\hline $\mathbf{H}$ & $\begin{array}{l}\text { Application of } \\
\text { Hinhulamrutadi } \\
\text { Malahara }\end{array}$ & $\begin{array}{l}\text { Till wound } \\
\text { heals or 21 } \\
\text { days }\end{array}$ \\
\hline $\mathbf{J}$ & $\begin{array}{l}\text { Application of } \\
\text { Jatyadi Ghrita } \\
\text { Prepared by SDM } \\
\text { pharmacy }\end{array}$ & $\begin{array}{l}\text { Till wound } \\
\text { heals or 21 } \\
\text { days }\end{array}$ \\
\hline
\end{tabular}

\section{Diagnostic Criteria:}

Diagnosis was made on the basis of Lakshanas of Dushtavrana like, Deergha kaleena, Pooti pooya, Ateeva vedana, Daha, Kandu, Shopha, Shonita srava (5) 


\section{Inclusion Criteria:}

Patients suffering from Dushtavrana of all types Dushtavrana within size of $7 \times 7 \mathrm{~cm}$ (length $\mathrm{x}$ breadth)

Exclusion Criteria:

Patients with disorders like Leprotic ulcer, Tubercular ulcer, HIV, HBsAg Positive patient will be excluded.

\section{Investigations:}

Blood, urine routine, culture and sensitivity if required.

\section{Intervention:}

Vrana is cleaned with normal saline. Then sterile gauze impregnated with Hingulamrutadi Malahara is applied on Dustavrana once in a day. Over it a sterile pad is placed and dressing done. This procedure is done until the proper healing is achieved. If the bandage becomes wet completely before 24 hours re-bandaging is done.

Assessment Criteria:

Vedana (Pain)

Table No. 2

\begin{tabular}{|l|l|l|}
\hline S.No. & Symptoms & Grading \\
\hline 1 & No pain & 0 \\
\hline 2 & $\begin{array}{l}\text { Pain during movement } \\
\text { but tolerable }\end{array}$ & 1 \\
\hline 3 & $\begin{array}{l}\text { Pain during movement } \\
\text { which affects the } \\
\text { movement }\end{array}$ & 2 \\
\hline 4 & $\begin{array}{l}\text { Pain even during rest } \\
\text { but not disturbing the } \\
\text { sleep }\end{array}$ & 3 \\
\hline 5 & $\begin{array}{l}\text { Continuous feeling of } \\
\text { pain disturbing the sleep } \\
\text { also }\end{array}$ & \\
\hline
\end{tabular}

2. Daha (Burning sensation)

Table No. 3

\begin{tabular}{|l|l|l|}
\hline S.No. & Symptoms & Grading \\
\hline 1 & No burning & 0 \\
\hline 2 & Little, localized & 1 \\
\hline 3 & Moderate localized & 2 \\
\hline 4 & More localized & 3 \\
\hline 5 & Continuous burning & 4 \\
\hline
\end{tabular}

3. Kandu (Itching)

Table No. 4

\begin{tabular}{|l|l|l|}
\hline S.No. & Symptoms & Grading \\
\hline 1 & No itching & 0 \\
\hline 2 & Slight & 1 \\
\hline 3 & Moderate & 2 \\
\hline 4 & More & 3 \\
\hline 5 & Continuous & 4 \\
\hline
\end{tabular}

4. Srava(Discharge)

Table No. 5

\begin{tabular}{|l|l|l|}
\hline S.No. & Symptoms & Grading \\
\hline 1 & No discharge & 0 \\
\hline 2 & gauze slight moist & 1 \\
\hline 3 & $\begin{array}{l}\text { gauze completely } \\
\text { wet }\end{array}$ & 2 \\
\hline 4 & $\begin{array}{l}\text { moist completely } \\
\text { within 24 hours }\end{array}$ & 3 \\
\hline
\end{tabular}

5. Gandha(Smell)

Table No.6

\begin{tabular}{|l|l|l|}
\hline S.No. & Symptoms & Grading \\
\hline 1 & No smell & 0 \\
\hline 2 & Minimum bad smell & 1 \\
\hline 3 & Moderate bad smell & 2 \\
\hline 4 & Unpleasant & 3 \\
\hline 5 & Foul smell & 4 \\
\hline
\end{tabular}

6. Akruti (Floor \& Granulation)

Table No. 7

\begin{tabular}{|l|l|l|}
\hline S.No. & Symptoms & Grading \\
\hline 1 & $\begin{array}{l}\text { Smooth, regular floor } \\
\text { \& with healthy } \\
\text { granulation tissue }\end{array}$ & 0 \\
\hline 2 & $\begin{array}{l}\text { Smooth, regular floor, } \\
\text { slight discharge, with } \\
\text { absence of slough }\end{array}$ & 1 \\
\hline 3 & $\begin{array}{l}\text { Smooth, irregular, } \\
\text { slight discharge, less } \\
\text { granulation tissue and } \\
\text { presence of slough }\end{array}$ & 2 \\
\hline 4 & $\begin{array}{l}\text { Rough floor and } \\
\text { presence of slough } \\
\text { with moderate } \\
\text { quantity of discharge }\end{array}$ & 3 \\
\hline 5 & $\begin{array}{l}\text { Rough, irregular floor } \\
\text { with more slough and } \\
\text { profuse discharge }\end{array}$ & \\
\hline
\end{tabular}


Observations and Results:

Table No.8 Age \& Sex wise distribution

\begin{tabular}{|l|l|l|l|l|l|l|}
\hline \multicolumn{3}{|l|}{ Group H } & \multicolumn{2}{l|}{ Group J } & & \\
\hline & Male & Female & Male & Female & Total & $\%$ \\
\hline $\mathbf{2 0 - 3 0}$ years & 0 & 1 & 1 & 0 & 2 & $5 \%$ \\
\hline $\mathbf{3 1 - 4 0}$ years & 2 & 0 & 2 & 2 & 6 & $15 \%$ \\
\hline 41-50 years & 5 & 1 & 1 & 3 & 10 & $25 \%$ \\
\hline $\mathbf{5 1 - 6 0}$ years & 4 & 2 & 7 & 1 & 14 & $35 \%$ \\
\hline 61-70 years & 3 & 1 & 2 & 0 & 6 & $15 \%$ \\
\hline$\geq 71$ years & 1 & 0 & 1 & 0 & 2 & $5 \%$ \\
\hline Total & 15 & 5 & 14 & 6 & 40 & 100 \\
\hline
\end{tabular}

Age \& Sex: Total 40 patients, in that 29 male and 11 females patients.

Table No.9 Occupation wise distribution

\begin{tabular}{|l|l|l|l|l|}
\hline Occupation & Group H & Group J & Total & \% \\
\hline Business & 4 & 2 & 6 & $15 \%$ \\
\hline Carpenter & 1 & 0 & 1 & $2.5 \%$ \\
\hline Coolie & 0 & 2 & 2 & $5 \%$ \\
\hline Driver & 1 & 1 & 2 & $5 \%$ \\
\hline Farmer & 7 & 7 & 14 & $35 \%$ \\
\hline House wife & 5 & 6 & 11 & $27.5 \%$ \\
\hline Security guard & 1 & 1 & 2 & $5 \%$ \\
\hline shopkeeper & 1 & 0 & 1 & $2.5 \%$ \\
\hline Teacher & 0 & 1 & 1 & $2.5 \%$ \\
\hline Total & $\mathbf{2 0}$ & $\mathbf{2 0}$ & $\mathbf{4 0}$ & $\mathbf{1 0 0}$ \\
\hline
\end{tabular}

Occupation: $35 \%$ of the patients were farmer and $27.5 \%$ were house wife

Table No.10 Appetite wise

\begin{tabular}{|l|l|l|l|l|}
\hline \multicolumn{1}{|c|}{ Appetite } & Group H & Group J & Total & $\%$ \\
\hline Good & 9 & 7 & 16 & $40 \%$ \\
\hline Moderate & 6 & 10 & 16 & $40 \%$ \\
\hline Poor & 5 & 3 & 8 & $20 \%$ \\
\hline Total & $\mathbf{2 0}$ & $\mathbf{2 0}$ & $\mathbf{4 0}$ & $\mathbf{1 0 0}$ \\
\hline
\end{tabular}

Appetite: $40 \%$ the patients were having good and $40 \%$ moderate appetite

Table No.11 Past History wise

\begin{tabular}{|l|l|l|l|l|}
\hline Past History & Group H & Group J & Total & $\%$ \\
\hline Diabetic & 8 & 4 & 12 & $30 \%$ \\
\hline HT & 1 & 1 & 2 & $5 \%$ \\
\hline DM and HT & 6 & 3 & 9 & $22.5 \%$ \\
\hline Others & 0 & 5 & 5 & $12.5 \%$ \\
\hline none & 5 & 7 & 12 & $30 \%$ \\
\hline Total & $\mathbf{2 0}$ & $\mathbf{2 0}$ & $\mathbf{4 0}$ & $\mathbf{1 0 0}$ \\
\hline
\end{tabular}

Past History: $30 \%$ patients were having diabeties and $22.5 \%$ patients diabetes with Hypertension 
Table No.12 Sleep wise distribution

\begin{tabular}{|l|l|l|l|l|}
\hline Sleep & Group H & Group J & Total & $\%$ \\
\hline Disturbed & 11 & 12 & 23 & $57.5 \%$ \\
\hline Sound & 9 & 8 & 17 & $42.5 \%$ \\
\hline Total & $\mathbf{2 0}$ & $\mathbf{2 0}$ & $\mathbf{4 0}$ & $\mathbf{1 0 0}$ \\
\hline
\end{tabular}

Sleep: $57.5 \%$ Patients were having disturbed sleep and $42.5 \%$ sound sleep

Table No.13 Arterial pulsation

\begin{tabular}{|l|l|l|l|l|}
\hline Arterial pulsation & Group H & Group J & Total & $\%$ \\
\hline Normal & 16 & 13 & 29 & $72.5 \%$ \\
\hline Diminished & 4 & 7 & 11 & $27.5 \%$ \\
\hline Total & $\mathbf{2 0}$ & $\mathbf{2 0}$ & $\mathbf{4 0}$ & $\mathbf{1 0 0}$ \\
\hline
\end{tabular}

Arterial pulsation: $\mathbf{7 2 . 5 \%}$ patients were having normal pulsation and $\mathbf{2 7 . 5 \%}$ diminished pulsation

Results:

Effect on Vedana (Pain):

Table No 14 Showing Effect on Vedana

\begin{tabular}{|l|l|l|l|}
\hline Vedana & $\begin{array}{l}\text { Grou } \\
\text { p H }\end{array}$ & $\begin{array}{l}\text { Grou } \\
\text { p J }\end{array}$ & $\begin{array}{l}\text { In } \\
\text { betwee } \\
\text { n } \\
\text { group }\end{array}$ \\
\hline $\begin{array}{l}\text { Mann- } \\
\text { Whitney U }\end{array}$ & - & - & 102.0 \\
\hline Wilcoxon W & - & - & 312.0 \\
\hline Z value & $\mathbf{- 3 . 9 0 1}$ & $\mathbf{- 3 . 1 2 6}$ & -2.783 \\
\hline P value & $<.001$ & $<.005$ & $<.005$ \\
\hline $\begin{array}{l}\text { Interpretatio } \\
\text { n }\end{array}$ & HS & $\mathbf{S}$ & $\mathbf{S}$ \\
\hline
\end{tabular}

HS- Highly significant, S- significant

In Group $\mathrm{H}$, obtained $\mathrm{z}$ value 3.901 and $p$ value .001 this is statistically highly significant which shows reduced Vedana.

On the other hand Group J obtained $\mathrm{z}$ value -3.126 and $\mathrm{p}$ value .002 which is statistically significant, shows reduced Vedana.

But when the comparison done in between the group higher mean rank in Group H than Group J, and p value is .005 which is significant, shows more effect in reduction of Vedana in Group $\mathrm{H}$ than group J.
Effect on Srava (Discharge):

Table No.15 Showing effect on Srava

\begin{tabular}{|l|l|l|l|}
\hline Srava & $\begin{array}{l}\text { Grou } \\
\text { p H }\end{array}$ & $\begin{array}{l}\text { Grou } \\
\text { p J }\end{array}$ & $\begin{array}{l}\text { In } \\
\text { betwee } \\
\text { n } \\
\text { group }\end{array}$ \\
\hline $\begin{array}{l}\text { Mann- } \\
\text { Whitney U }\end{array}$ & - & - & 68.50 \\
\hline Wilcoxon W & - & - & 278.5 \\
\hline Z value & -3.893 & -3.502 & -3.685 \\
\hline P value & $<.001$ & $<.001$ & $<.001$ \\
\hline $\begin{array}{l}\text { Interpretatio } \\
\text { n }\end{array}$ & HS & HS & HS \\
\hline
\end{tabular}

HS- Highly significant

In Group $\mathrm{H}$, obtained $\mathrm{z}$ value -3.893 and $\mathrm{p}$ value .001 this is statistically highly significant which shows decreased Srava.

On the other hand Group $\mathrm{J}$ obtained $\mathrm{z}$ value -3.502 and $p$ value .001 which is statistically highly significant, shows reduced Srava

But when the comparison done in between the group higher mean rank in Group $\mathrm{H}$ than Group J, and p value is .001 which is highly significant, shows more effect in reduction of Srava in Group H than group $\mathrm{J}$. 
Effect on Gandha (Smell):

Table No.16 Showing effect on Gandha

\begin{tabular}{|l|l|l|l|}
\hline Gandha & $\begin{array}{l}\text { Grou } \\
\text { p H }\end{array}$ & $\begin{array}{l}\text { Grou } \\
\text { p J }\end{array}$ & $\begin{array}{l}\text { In } \\
\text { betwee } \\
\text { n } \\
\text { group }\end{array}$ \\
\hline $\begin{array}{l}\text { Mann- } \\
\text { Whitney U }\end{array}$ & - & - & 59.00 \\
\hline Wilcoxon W & - & - & 269.00 \\
\hline Z value & -3.769 & -3.275 & -3.685 \\
\hline P value & .001 & .001 & .001 \\
\hline $\begin{array}{l}\text { Interpretatio } \\
\text { n }\end{array}$ & HS & HS & HS \\
\hline
\end{tabular}

\section{HS- Highly significant}

In Group $\mathrm{H}$, obtained $\mathrm{z}$ value -3.769 and $\mathrm{p}$ value .001 which is statistically highly significant, this shows decreased Gandha.

On the other hand Group $\mathrm{J}$ obtained $\mathrm{z}$ value -3.275 and $\mathrm{p}$ value .001 which is statistically highly significant, shows reduced Gandha.

But when the comparison done in between the group higher mean rank in Group H than Group J, and p value is .001 which is highly significant, shows more effect in reduction of Gandha in Group H than group $\mathrm{J}$

Effect on Kandu (Itching):

Table No.17 Showing effect on Kandu

\begin{tabular}{|l|l|l|l|}
\hline Gandha & $\begin{array}{l}\text { Grou } \\
\text { p H }\end{array}$ & $\begin{array}{l}\text { Grou } \\
\text { p J }\end{array}$ & $\begin{array}{l}\text { In } \\
\text { betwee } \\
\text { n } \\
\text { group }\end{array}$ \\
\hline $\begin{array}{l}\text { Mann- } \\
\text { Whitney U }\end{array}$ & - & - & 158.00 \\
\hline Wilcoxon W & - & - & 368.00 \\
\hline Z value & -3.578 & -3.272 & -1.214 \\
\hline P value & $<.001$ & $<.001$ & $>.005$ \\
\hline $\begin{array}{l}\text { Interpretatio } \\
\text { n }\end{array}$ & HS & HS & NS \\
\hline
\end{tabular}

HS- Highly significant NS- Non significant

In Group $\mathrm{H}$, obtained $\mathrm{z}$ value -3.578 and $\mathrm{p}$ value .001 which is statistically highly significant, which shows reduced Kandu.
On the other hand Group $\mathrm{J}$ obtained $\mathrm{z}$ value -3.272 and $\mathrm{p}$ value .001 which is statistically highly significant, shows reduced Kandu.

But when the comparison done in between the group higher mean rank in Group H than Group J, and p value is .225 which is non-significant, shows no effect in reduction of Kandu in Group 1 than group.

Effect on Daha (Burning):

Table No.18 showing effect on Daha

\begin{tabular}{|l|l|l|l|}
\hline Daha & $\begin{array}{l}\text { Grou } \\
\text { p H }\end{array}$ & $\begin{array}{l}\text { Grou } \\
\text { p J }\end{array}$ & $\begin{array}{l}\text { In } \\
\text { betwee } \\
\text { n } \\
\text { group }\end{array}$ \\
\hline $\begin{array}{l}\text { Mann- } \\
\text { Whitney U }\end{array}$ & - & - & 173.00 \\
\hline Wilcoxon W & - & - & 383.00 \\
\hline Z value & -3.963 & -3.236 & -.779 \\
\hline P value & $<.001$ & $<.001$ & $>.005$ \\
\hline $\begin{array}{l}\text { Interpretatio } \\
\text { n }\end{array}$ & HS & HS & NS \\
\hline
\end{tabular}

HS- Highly significant NS- Non significant

In Group H, obtained z value -3.963 and $p$ value .001 which is statistically highly significant, which shows reduced Daha.

In Group 2 obtained z value -3.236 and $\mathrm{p}$ value .001 which is statistically highly significant, shows reduced Daha. But when the comparison done in between the group higher mean rank in Group $\mathrm{H}$ than Group J, and p value is .436 which is non-significant, shows no effect in reduction of Daha in Group H than group $\mathrm{J}$

Effect on Akruti (Granulation)

Table No.19 showing effect on Akruti (Granulation)

\begin{tabular}{|l|l|l|l|}
\hline $\begin{array}{l}\text { Akruti } \\
\text { (Granulation }\end{array}$ & $\begin{array}{l}\text { Grou } \\
\text { p H }\end{array}$ & $\begin{array}{l}\text { Grou } \\
\text { p J }\end{array}$ & $\begin{array}{l}\text { In } \\
\text { betwee } \\
\text { n } \\
\text { group }\end{array}$ \\
\hline Mann- & - & - & 14.00 \\
\hline
\end{tabular}




\begin{tabular}{|l|l|l|l|}
\hline Whitney U & & & \\
\hline Wilcoxon W & & & 224.00 \\
\hline Z value & -4.093 & -3.317 & -5.285 \\
\hline P value & $<.001$ & $<.001$ & $<.001$ \\
\hline $\begin{array}{l}\text { Interpretatio } \\
\text { n }\end{array}$ & HS & HS & HS \\
\hline
\end{tabular}

\section{HS- Highly significant}

In Group $\mathrm{H}$, obtained $\mathrm{z}$ value 4.093 and $p$ value .001 which is statistically highly significant, this shows good granulation.

On the other hand Group $\mathbf{J}$ obtained $\mathrm{z}$ value -3.317 and $\mathrm{p}$ value .001 which is statistically highly significant, shows good granulation

But when the comparison done in between the group higher mean rank in Group H than Group J, and p value is .001 which is highly significant, shows more effect in good granulation $\mathrm{H}$ than group $\mathrm{J}$.

\section{Effect on Length}

Table No.20 showing effect on Length

\begin{tabular}{|l|l|l|l|}
\hline Length & $\begin{array}{l}\text { H } \\
\text { group }\end{array}$ & $\begin{array}{l}\text { J } \\
\text { group }\end{array}$ & $\begin{array}{l}\text { In } \\
\text { between } \\
\text { group }\end{array}$ \\
\hline Mean & 2.0500 & 1.1000 & 2.000 \\
\hline $\begin{array}{l}\text { Std. } \\
\text { Deviation }\end{array}$ & .99868 & 1.1192 & 1.025 \\
\hline $\begin{array}{l}\text { Std. Error } \\
\text { Mean }\end{array}$ & .22331 & .25026 & .2294 \\
\hline t value & 9.180 & 4.395 & 2.651 \\
\hline P value & $<.005$ & $<.005$ & $>.005$ \\
\hline Interpretation & $\mathbf{S}$ & $\mathbf{S}$ & $\mathbf{N S}$ \\
\hline
\end{tabular}

The observed $t$ value $(t=2.651)$ has a $p$ value of .012 which is more than 0.05 with degrees of freedom. Therefore, the test is non significant at 5\% level of significance. Hence it is concluded that there is no significant difference in the efficacy of the two drugs in case of changes in length

\section{Effect on Breadth}

Table No.21 showing effect on Breadth

\begin{tabular}{|l|l|l|l|}
\hline Length & H group & $\begin{array}{l}\text { J } \\
\text { group }\end{array}$ & $\begin{array}{l}\text { In } \\
\text { betwee } \\
\text { n } \\
\text { group }\end{array}$ \\
\hline Mean & 1.90000 & .80000 & 1.9500 \\
\hline $\begin{array}{l}\text { Std. } \\
\text { Deviation }\end{array}$ & .96791 & .83351 & .99868 \\
\hline $\begin{array}{l}\text { Std. Error } \\
\text { Mean }\end{array}$ & .21643 & .18638 & .22331 \\
\hline t value & 8.779 & 4.292 & 3.954 \\
\hline P value & $<.005$ & $<.005$ & $<.005$ \\
\hline $\begin{array}{l}\text { Interpretati } \\
\text { on }\end{array}$ & $\mathbf{S}$ & $\mathbf{S}$ & $\mathbf{S}$ \\
\hline
\end{tabular}

The observed $t$ value $(t=3.954)$ has a $p$ value of .001 which is less than 0.05 with degrees of freedom. Therefore, the test is significant at $5 \%$ level of significance. Hence it is concluded that there is significant in the efficacy of the two drugs in case of changes in breadth.

\section{Case}

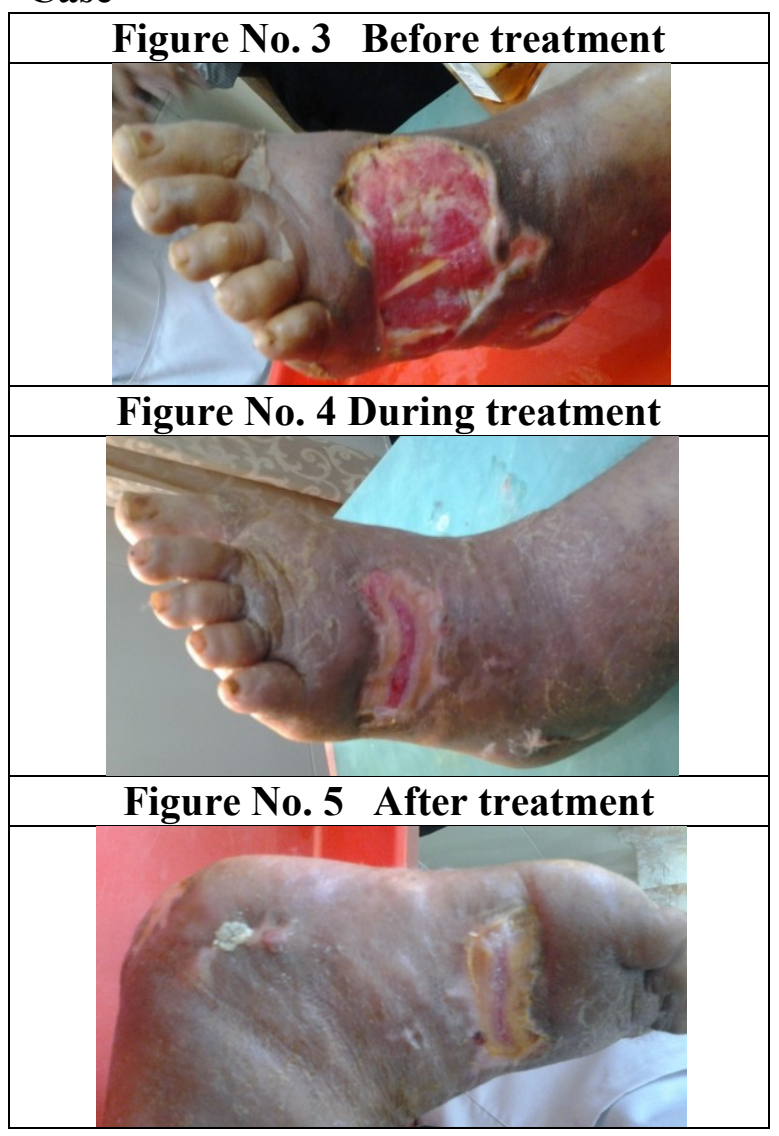


Mode of Action of Hingulamrutadi Malahara:

- One of main ingredient is Rasa Karpura, having Tridoshahara \& Vedanahara properties and is the reason to reduce pain

- To reduce Srava drug should have Kaphahara, Laghu, Ruksha guna, Kashaya rasa Grahi, Usna veerya and Vranashodhaka properties. In this formulation Rasakarpura, Tankana and Panchvalkala Kashaya are having these qualities. So may help to reduce Srava

- Sphatika is Madhura rasa, Sheeta, Snigdhaguna, Sheetaveerya

- Panchavalkala is Tikta Kashaya rasa, Sheeta veerya, Pitta Shamaka can be probable reason to reduce Daha

- Kandu can be controlled with drugs which is having Katu rasa, Usnaveerya, Kapha Shamaka, Tridoshahara, Twak doshahara, Vishahara so Hingula, Rasakarpura is having all these properties, which reduces Kandu

- Kapha-pitta hara, Vranashodhaka, Ruksha, Grahi are the properties to control the Puyanirharana and its Gandha

- So here in this formulation, Hingula, Rasakarpura, Tankana, Sphatika, Panchavalkala Kashaya is useful for Vrana shodhana and Ropana

\section{Effect of Hingulamrutadi Malahara:} Hingulamrutadi Malahara is a compound preparation, 20 patients of Dustavrana were treated with application.

Patients got significant relief in Vedana, Srava, Daha, Gandha, and Kandu, Vrana became Shuddha followed by Vrana Ropana.

Effect of Jatyadi Ghrita: Jatyadi Ghrita was selected as a control group drug, 20 patients of Dustavrana were treated with Jatyadi Ghrita, and followings are the reductions of signs and symptoms after applying Jatyadi Ghrita. There is a significant reduction in the Vedana, Srava, Gandha and marked relief in Kandu, size of the ulcer, granulation and no relief in Daha, Vrana became Shuddha and healing was started.

Comparision of the effect: Comparison of result was done in Group $\mathrm{H}$ (Hingulamrutadi Malahara) and Group J(Jatyadi ghrita) by Independent Sample tTest, Mann-Whitney U Test.

Significant improvement were there on Srava, Gandha, size of ulcer by Hingulamrutadi Malahara compaired to Jatyadi ghrita. Pain intensity was less compaired to Jatyadi ghrita and granulation tissue was better in Hingulamrutadi malahara.

\section{Conclusion:}

On the basis of the discussions it can be concluded that Hingulamrutadi Malahara was better in providing relief to the patients of DushtaVrana in comparison to Jatyadi Ghrita

In total Hingulamrutadi Malahara with its Puyanirharana, Vrana Shodhana properties can be efficient enough to convert Dustavrana into ShuddhaVrana.

Further Vrana Utsadana function of the preparation may thus accelerate the healing of Vrana

\section{References:}

1. Dr.Anant Ram Sharma. Sushruta Samhita with Susrutavimarshini Hindi commentary. Edited by, Chaukambha Surabharati Prakashan. Varanasi; vol 1 Reprint - 2008, sutrasthana 22/7 p192

2. Vaidya Yadavji Trikamjiacharya:Sushruta samhitha with Dalhanacharya Nibhandhasangraha and Gayadasacharya Nyaychandrika Panjika commentary edited by Krishnadas Academy, Varanasi, reprint 2010, chikitsasthana 3/86, p414. 
3. Anant Ram Sharma. Sushruta Samhita with Susrutavimarshini Hindi commentary. Edited by, Chaukambha Surabharati Prakashan. Varanasi; vol 1 Reprint - 2008, sutrasthana 1/(1) p5

4. Vaidya Yadavji Trikamjiacharya: Sushruta samhitha with Dalhanacharya Nibhandhasangraha and Gayadasacharya Nyaychandrika
Panjika commentary edited by Krishnadas Academy, Varanasi, reprint 2010, sutraasthana 22/6, p108

5. Pranacharya Sree Sadananda Sharma Virachita Hindi commentary by Pandit Kasinatha Sastri Rasa Tarangini by published by Mothilal Banarasi das varanasi, 11th edition 2000 9th Taranga 27-31 Shloka page no 205 